\title{
Disinfection of rainwater as a way to their microbiological stability and safe use
}

\author{
Monika Zdeb ${ }^{1, *}$, Justyna Zamorska ${ }^{1}$, and Andżelika Pietrzyk ${ }^{1}$ \\ ${ }^{1}$ Department of Water Protection and Purification, Rzeszow University of Technology, al. \\ Powstańców Warszawy 12, 35-095 Rzeszów, Poland
}

\begin{abstract}
Research on the microbiological quality of rainwater collected from roof surfaces indicates their significant contamination with microorganisms, including potentially pathogenic ones. The aim of the research was to attempt disinfection of rainwater with chemical methods and to evaluate the effectiveness of this disinfection. The research was carried out with the use of appropriate means in the case of decontamination of large volumes of water, when it is important to maintain their biological stability - chlorination and ozonation. After the disinfector was administered for 4 weeks, bacterial microflora (stability) was observed in stored water. The control was carried out by determining the total amount of bacteria at $37^{\circ} \mathrm{C}$ and the total amount of bacteria at $22^{\circ} \mathrm{C}$ on the reference medium (agar A) and on the non-standard substrate (R2A agar). The number of indicator bacteria was also determined: fecal streptococci and Escherichia coli (on the chromogenic medium). Changes in the amount of microorganisms after disinfection processes were also monitored by flow cytometry. The research results clearly indicate better chlorinating disinfection effects. It allows the removal of indicator microorganisms in a relatively short time (1 hour), and the effect of the disinfectant lasts up to about a half month.
\end{abstract}

\section{Introduction}

The presence of pathogenic bacteria in rainwater encourages the development of appropriate disinfection systems. Appropriately selected disinfectants and disinfection procedures will destroy spores and waterborne pathogens, but most of all they will stop the spread of infectious diseases in water, which will be directed to human consumption and economic needs [1].

Various physical and chemical methods can be used to reduce microflora in rainwater. Solar panels enable temperature inactivation of pathogenic bacteria [2, 3], membrane filtration allows to stop $99 \%$ of all microorganisms, similarly to sand filters [4]. Rapid gravity filtration systems on polyethylene sulfone filters are also used [5]. Chemical methods such as chlorination [6], or using silver ions [7] effectively and permanently inactivate bacteria, including pathogenic bacteria.

\footnotetext{
${ }^{*}$ Corresponding author: $\underline{\text { mzdeb@prz.edu.pl }}$
} 
An important aspect is also the determination of the actual effectiveness of disinfection and the time for which this effect persists. In Poland, there are no standards or regulations regarding the methodology for testing rainwater quality. There were also no studies to improve the quality, especially of microbial rainwater. The article attempts to disinfect rainwater collected from a roof covered with concrete tiles, and then to monitor changes in the microbiological quality of this water by indirect methods (plate methods) and direct method (flow cytometry).

\section{Research methodology}

Disinfection of rainwater taken from a roof covered with concrete tiles was carried out, due to the prevalence of this type of roofing and significant microbiological contamination of collected rainwater. The research applied chemical disinfectants: chlorine and ozone. Chlorination was carried out using a commonly used chlorine preparation used in home basins, in which the active substance is dihydrate sodium dichloroisocyanuric acid $\left(\mathrm{C}_{3}-\mathrm{H}-\mathrm{Cl}_{2}-\mathrm{N}_{3}-\mathrm{O}_{3} . \mathrm{Na}_{2} \mathrm{H}_{2}-\mathrm{O}\right)$. Dosage of the preparation according to the manufacturer's instructions allows to obtain $56 \%$ concentration of free chlorine in water. Based on this information, the dose was calculated for a fixed volume of water to obtain 2 and $3 \%$ free chlorine. Ozonation process used to technical ozonator ZY-H10, 230, which can produce ozone in an amount of $7 \mathrm{mg} \mathrm{O}_{3} / \mathrm{hr}$. The ozonation time for the tested rainwater was experimentally determined - 20 and 30 minutes. For this purpose, ozonation of small volumes of the tested rainwater $(250 \mathrm{ml})$ was performed in several times and the efficiency of the process was checked by plate cultures on the reference agar medium and on the R2A agar. Proper examination of the effectiveness of disinfection processes was carried out in a volume of 4.5 litters. Disinfected rainwater was stored in polyethylene canisters at a temperature of $12^{\circ} \mathrm{C}$ (microbial incubators). The study of biological stability of rain water was carried out for 30 days from the task of the disinfector (after 0.5 hours, and after 1, 2, $3,5,7,14$ and 28 days). Both for the disinfection variant with ozone and chlorine, the following microbiological parameters were determined:

- determining the number of bacteria in $37^{\circ} \mathrm{C}$ and the number of bacteria in $22^{\circ} \mathrm{C}$ by plate cultures on reference agar A and on depleted R2A agar,

- determination of the number of coliforms by membrane filters on Endo medium and Escherichia coli on a chromogenic medium,

- determining the number of faecal streptococci by the membrane filter method,

- determining the number of Clostridium perfingens by plate cultures,

- determination of microorganisms counts by flow cytometry.

\section{Test results}

In the control test (without disinfectant), the amount of psychrophilic bacteria remained stable until the $28^{\text {th }}$ day of storage (Fig. 1). 


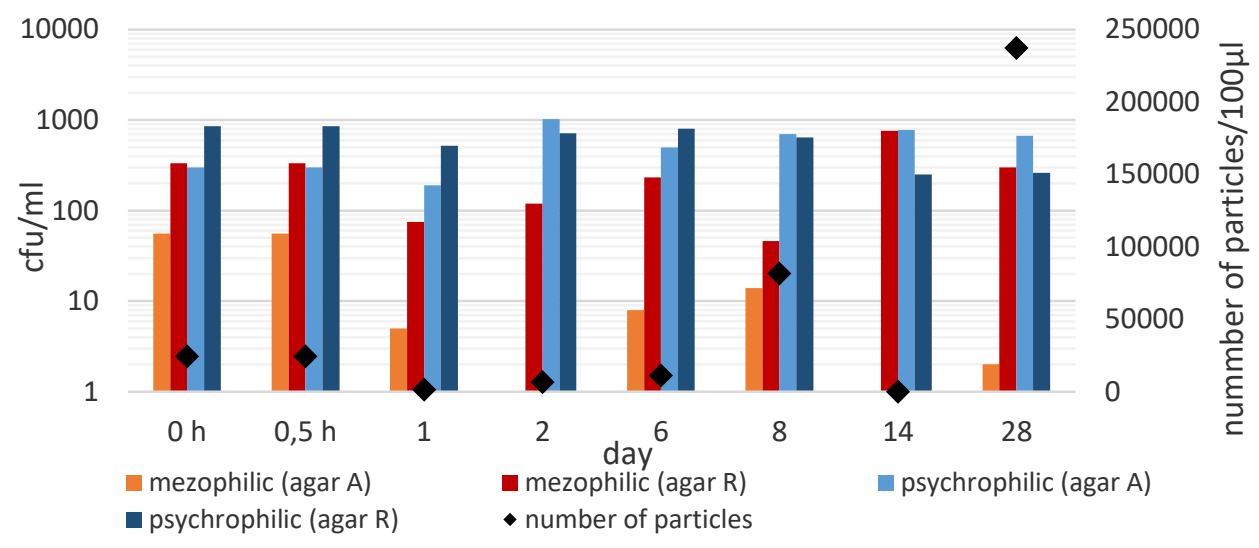

Fig. 1. Changes in the microbiological quality of rainwater during storage (without disinfectant).

There are also clear differences in the number of microorganisms propagated on various microbiological substrates. The number of bacteria is mostly greater for R2A agar cultures, which is especially true for mesophilic bacteria. On the 14th day after the task of the disinfectant, these bacteria did not multiply on the reference medium, which could be related to the temperature of storage of rainwater $\left(12^{\circ} \mathrm{C}\right)$. Only the amount of mesophilic bacteria decreased from 80 to $20 \mathrm{cfu} / \mathrm{ml}$. The number of psychrophilic bacteria fluctuated within $400-900 \mathrm{cfu} / \mathrm{ml}$ on agar A and $400-1000 \mathrm{cfu} / \mathrm{ml}$ on R2A agar.

The chlorine effect was recorded after half an hour for tasks (Fig. 2 and 3). However, the greatest effects are observed only after the day (it may be due to the character of the chlorine preparation - it was a granulate).

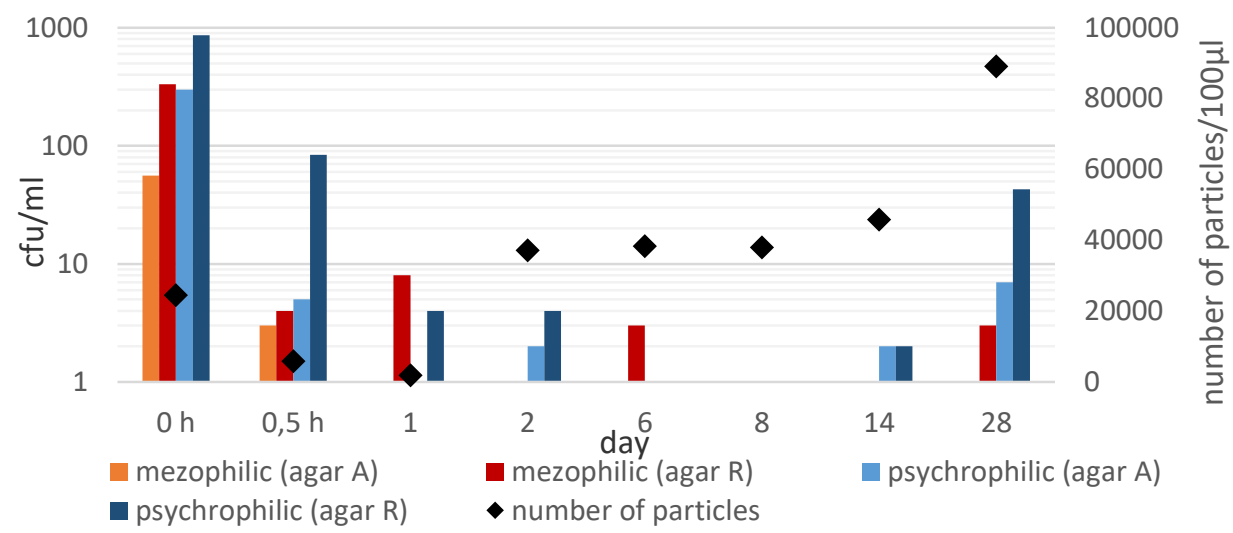

Fig. 2. Control of changes in microbiological quality of rainwater after chlorine disinfection (2\%). 


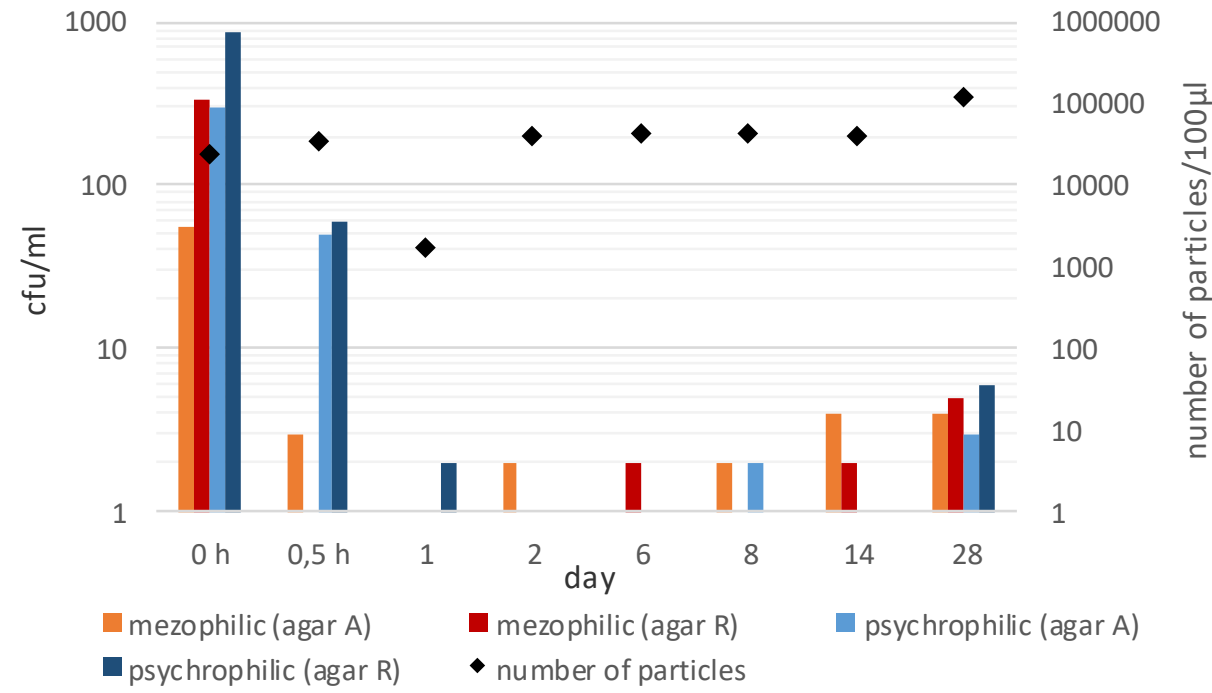

Fig. 3. Control of changes in microbiological quality of rainwater after chlorine disinfection (3\%).

For disinfection with $2 \%$ chlorine, a significant increase in the number of microorganisms was observed on the $28^{\text {th }}$ day after the preparation task. In the case of $3 \%$ free chlorine concentration, bacterial microflora has not been reproduced yet. A slight increase in the number of mesophilic bacteria was recorded on the 14th day after the disinfector was given. Not only chemical methods can eliminate pathogenic organisms. In order to improve the microbiological quality of rainwater, it is also possible to use physical methods [4]. Amin and Han made an experimental design in which they put PET bottles filled with rainwater. The obtained temperatures at the level of $40-50^{\circ} \mathrm{C}$, allowed for a significant reduction of Escherichia coli (from 250 to several cfu/100ml) after 9 hours of exposure [8]. However, the operation of these methods is completely dependent on atmospheric conditions and requires additional activities related to, for example, filling bottles or transferring them to the roof.

Determination of the number of indicator bacteria indicates the effective operation of the chlorination method (tab. 1).

Table 1. Changes in the number of indicator bacteria in rainwater after chlorine disinfection.

\begin{tabular}{|c|c|c|c|c|c|c|}
\hline $\begin{array}{c}\text { Microbiological } \\
\text { indicator }\end{array}$ & \multicolumn{2}{|c|}{ Fecal streptococci } & \multicolumn{2}{c|}{ Coliforms } & \multicolumn{2}{c|}{ Escherichia coli } \\
\hline Dose of chlorine & $\mathbf{2 \%}$ & $\mathbf{3 \%}$ & $\mathbf{2 \%}$ & $\mathbf{3 \%}$ & $\mathbf{2 \%}$ & $\mathbf{3 \%}$ \\
\hline $\begin{array}{c}\text { Before } \\
\text { didinfection }\end{array}$ & \multicolumn{2}{|c|}{6} & \multicolumn{2}{|c|}{2} & \multicolumn{2}{|c|}{3} \\
\hline 1 hour & 0 & 0 & 0 & 0 & 0 & 0 \\
\hline 1 day & 0 & 0 & 0 & 0 & 0 & 0 \\
\hline 2 days & 0 & 0 & 0 & 0 & 0 & 0 \\
\hline 4 days & 0 & 0 & 0 & 0 & 0 & 0 \\
\hline 5 days & 0 & 0 & 0 & 0 & 0 & 0 \\
\hline 7 days & 0 & 0 & 0 & 0 & 0 & 0 \\
\hline 14 days & 0 & 0 & $\mathbf{1}$ & 0 & 0 & 0 \\
\hline 30 days & 0 & 0 & $\mathbf{1}$ & 0 & 0 & 0 \\
\hline
\end{tabular}


Already in the first hour of chlorine action a complete reduction of coliforms and Enterococci was observed. It was not until 14 days after the disinfectant task that single cells of coli bacteria were detected.

The ozonation trials of rainwater intended for storage were much less favorable (Fig. 4 and 5).
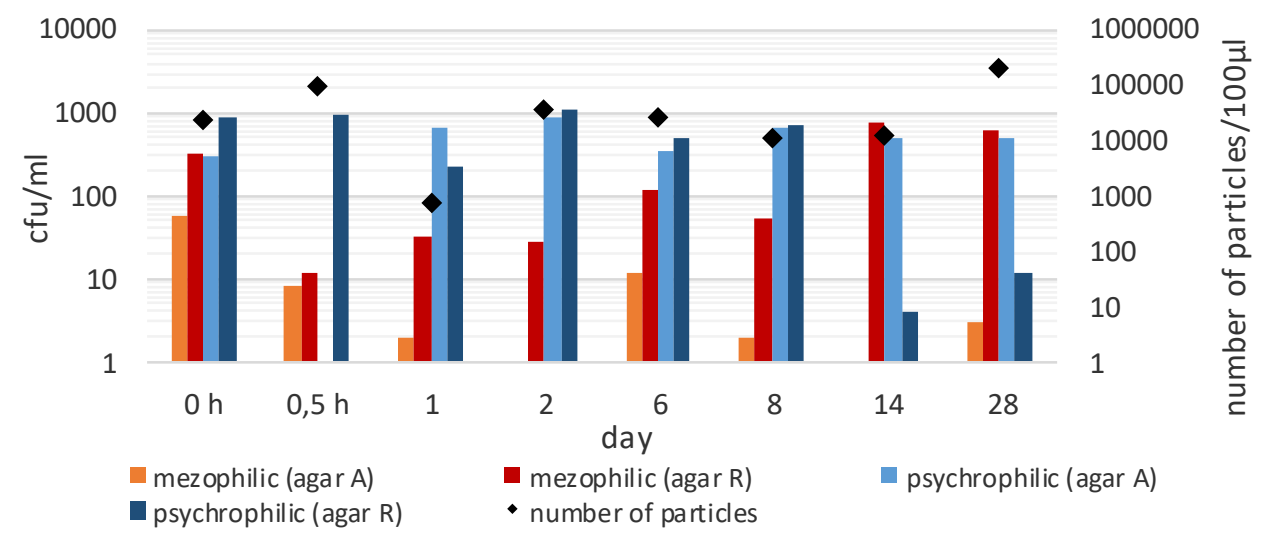

Fig. 4. Control of changes in microbiological quality of rainwater after ozone disinfection for 20 minutes.

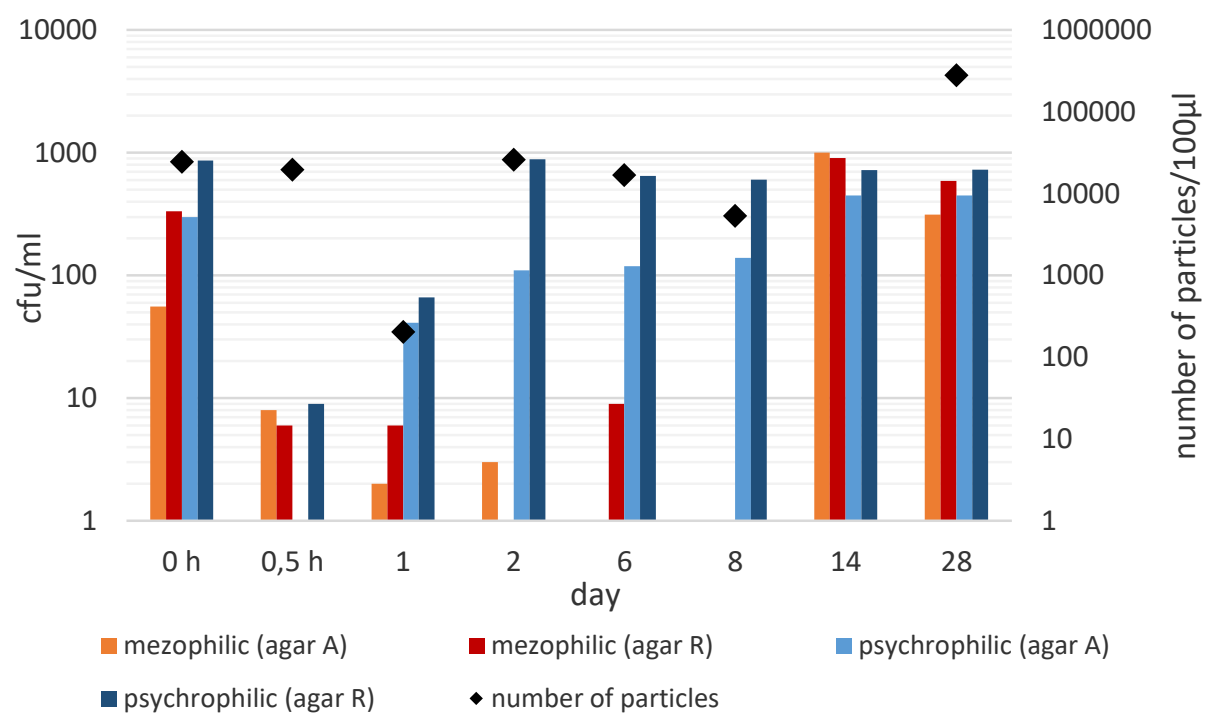

Fig. 5. Control of changes in microbiological quality of rainwater after ozone disinfection for 30 minutes.

Already after 2 weeks an increase in the number of mesophilic and psychrophilic bacteria was observed despite the storage of water at low temperature $\left(12^{\circ} \mathrm{C}\right)$. It is worth noting that in both cases the amount of bacteria was not significantly reduced in the initial phase of disinfection.

In the case of disinfection with ozone, colonies of pathogenic bacteria were observed already on the 5th day after disinfection, and after a month their number reached several hundred (tab. 2). 
Table 2. Changes in the number of indicator bacteria in rainwater after the ozone disinfection process.

\begin{tabular}{|c|c|c|c|c|c|c|}
\hline $\begin{array}{c}\text { Microbiological } \\
\text { indicator }\end{array}$ & \multicolumn{2}{|c|}{ Fecal streptococci } & \multicolumn{2}{c|}{ Coliforms } & \multicolumn{2}{c|}{ Escherichia coli } \\
\hline Ozonation time & $\mathbf{2 0}$ min. & $\mathbf{3 0}$ min. & $\mathbf{2 0}$ min. & $\mathbf{3 0}$ min. & $\mathbf{2 0}$ min. & $\mathbf{3 0}$ min. \\
\hline $\begin{array}{c}\text { Before } \\
\text { disinfection }\end{array}$ & \multicolumn{2}{|c|}{6} & \multicolumn{2}{c|}{2} & \multicolumn{2}{c|}{3} \\
\hline 1 hour & 0 & 0 & 0 & 0 & 0 & 0 \\
\hline 1 day & 0 & 0 & 0 & 0 & 0 & 0 \\
\hline 2 days & 0 & 0 & 0 & 0 & 0 & 0 \\
\hline 4 days & 0 & 0 & 0 & 0 & 0 & 0 \\
\hline 5 days & 0 & 0 & 0 & 0 & 1 & 0 \\
\hline 7 days & 1 & 0 & 0 & 0 & 1 & 3 \\
\hline 14 days & 1 & 0 & 2 & 0 & 3 & 3 \\
\hline 30 days & 1 & 0 & 650 & 660 & 80 & 15 \\
\hline
\end{tabular}

Plate methods which is used in presented research are extremely time-consuming and burdened with a large error, because most living bacterial cells do not multiply under laboratory conditions and under environmental stress conditions, resulting in significantly lower results [9]. Therefore, the R2A agar medium and flow cytometry were used to determine the number of cells in rainwater. The latter method is a direct identification and used so far mainly in laboratory diagnostics to determine the number of apoptotic cells and atypical (cancerous) cells. The indication of the number of living cells, by means of the cytometry, for each water tested was higher is higher than indicated by plate methods, but always proportional to the results obtained from traditional cultures. The possibilities of using flow cytometry to determine the number of microorganisms cells in water subjected to disinfection processes are confirmed by studies on the quality of tap water $[10,11]$. Correlation of the number of microorganisms indicated during cultures and in cytometric studies cannot be taken literally. The plate method only indicates the number of bacteria that are able to multiply under laboratory conditions. By means of cytometry, the number of all microorganisms present in the water sample is directly determined. This is well illustrated by diagrams 4 and 5 . After 0.5 hour from the end of ozonation, plate methods show a clear decrease in the number of mesophilic and psychrophilic bacteria. No changes were observed in the case of cytometry. On the other hand, the more effective effect of chlorine is marked not only by the results of plate methods, but also by the cytometric method (Fig. 2 and 3). After the first day, the number of microorganisms was lowered. However, the usefulness of cytometric determinations to control changes in water quality, for example after disinfection processes, is found.

\section{Conclusion}

- The use of rainwater chlorination method proved to be more effective in comparison to ozonation.

- A significant improvement in the microbiological quality, assessed by the amount of psychrophilic and mesophilic bacteria in rainwater, was observed after the first day of chlorine treatment.

- The results of ozonation of rain water did not bring decent results. No significant reduction of mesophilic and psychrophilic bacteria. 
- The use of chlorination and ozonation in rainwater it allows the removal of indicator microorganisms in a relatively short time (1 hour).

- The reproduction of the indicator bacterial bacteria after the chlorine disinfection process took place on the 14th day and after the ozone treatment on the 5th day.

- The results of studies on the amount of microorganisms by means of flow cytometry indicate the applicability of this determination in determining the degree of microbial contamination and microflora recovery after the disinfection process.

- Reproduction of microorganisms in stored rainwater after disinfection processes prompts further research into the impact of the material from which the tank is made for its storage.

\section{References}

1. J. Nawrocki, A. Biłozor, Uzdatnianie wody. Procesy chemiczne i biologiczne (Praca zbiorowa, Wyd. Naukowe PWN, 2000)

2. M.T. Amin, M.Y. Han, Water Sci. Technol. 60, 2 (2009)

3. R. Nalwanga, C. K. Muyanja, G. K. Mc Guigan, B. Quilty, Journal of Environmental Chemical Engineering (2016)

4. V. Naddeo, D. Scannapieco, V. Belgiorno, Journal of Hydrology, 498 (2013)

5. Q. Ding, A. Schweiger, M. L'Heureux, D. Battisti, S. Po-Chedly, N. Jonshon, E. Blanchard-Wrigglesworth, K. Harnos, Q. Zhang, R. Estman, E. Steig, Nature Climate Change, 7 (2017)

6. R.F.M. Neto, M.L. Calijuri, I. de Castro Carvalho, A. da Fonseca Santiago, Resources, Conservation and Recycling, 65 (2012)

7. M. Nawaz, M.Y. Han, T. Kim, U. Manzoor, M.T. Amin, Science of the Total Environment (2012)

8. M.T. Amin, M.Y. Han, Desalination, 276 (2011)

9. K.E. Heim, A.R. Tagliaferro, D.J. Bobilya, J.Nutr. Biochem. 13, 10 (2002)

10. J. Zamorska, D. Papciak, M. Zdeb, JCEEA, 62 (2015)

11. J. Zamorska, Cytometria przeplywowa jako nowe narzędzie do oceny jakości mikrobiologicznej wody, materiaty konferencyjne (DEZ-WOD, 2017) 